\title{
World System Analysis of Biomedical Hegemony
}

\author{
Anwaar Mohyuddin', Mamonah Ambreen'2, Juhi Naveed1, Danish Ahmad1 \\ ${ }^{1}$ Department of Anthropology, Quaid-i-Azam University, Islamabad, Pakistan \\ ${ }^{2}$ Distance, Non-Formal \& Continuing Education (DNFCE), Allama Iqbal Open University, Islamabad, Pakistan \\ Email: unwaar@gmail.com
}

Received 16 February 2014; revised 16 March 2014; accepted 11 April 2014

Copyright (C) 2014 by authors and Scientific Research Publishing Inc.

This work is licensed under the Creative Commons Attribution International License (CC BY). http://creativecommons.org/licenses/by/4.0/

cc) (i) Open Access

\section{Abstract}

This paper deals with research findings regarding traditional and modern biomedical healthcare systems prevailing in the Village Zandra, District Ziarat in the province of Balochistan. An effort has been made to find out the medical system working in the village which included both beliefs and perceptions related to health and illness and also the activities which natives have adopted or developed to maintain and restore their health. Initially the natives were using traditional and spiritual healing systems, but now, as their economic condition and literacy rate are improving, they are more inclined towards the modern methods of treatment. During the last 3 decades, few changes have been witnessed. Shift from subsistence to market economy has increased the use of allopathic medicines due to the fact that the natives have started opting for secondary sources of income. Besides, researcher endeavored to explore the shift from traditional to modern healthcare and the disparity between natives' health related beliefs and practices. The impact of these changes has been analyzed in light of world system theory at micro level. The data presented in this paper have been collected by using qualitative anthropological research techniques.

\section{Keywords}

Health, Illness, Believe System, Core, Periphery, Pharmaceutical Industry, Exploitation

\section{Introduction}

The term traditional medicine implies medical techniques traditionally developed and used in various societies which include herbal medicine, Ayurveda medicine, Acupuncture traditional Chinese medicine and Homeopathy. Traditional Medicine entails the use of many items such as herbs, leaves, oil, etc. Traditional healers can make use of natural resources commonly found in their environment. Traditional medicine is less costly. 
The locale of research is in transition from traditional to modern way of life due to economic uplift, education in the area and local's contact with the outside world. During this transition, changes have also occurred in the beliefs regarding the phenomena of health and illness and also in the mode of treatment used by the native people, which resulted in the adoption of an allopathic mode of treatment. Despite that, the people of the village still carry their traditional health related beliefs and traditional ways of treatment (use of faith healers and home remedies) along with allopathic mode. Thus the pluralistic mode of treatment is prevailing in the village, and therefore, in Zandra, beliefs about health and illness have elements of both modern and traditional beliefs (related to health and illness).

The majority of the elderly people do not like the modern medicines because of their side effects. They think that the patient has to recover twice, first from the illness and then from the side effects of the medicine. The disease continues to persist and returns back in a different form at a different time. Moreover, these medicines produce dietary deficiencies by destroying the body's natural nutrients. The root cause of disease is free flow of toxins in our body, created by emotional disturbance, un-healthy food, lack of physical exercise, etc. and these modern medicines produce even more toxins at a time when the body is least capable of coping with it. Therefore, the power to cure lies not in these medicines, but in nature.

The meaning of health changes with time and social conditions of men. Health in the hygienic sense, evolved over thousands of years as an approach for survival and long life. Having good health is one of the basic needs of all human societies. The definitions of health have been broadened to encompass social and emotional factors, rather than being restricted to clinical criteria. The constitution of the World Health Organization (WHO) defines health as a complete state of physical, mental and social wellbeing and not merely the absence of illness. In other words, health is the condition of the body in which all its parts are functioning efficiently and in a routine manner. Health is an issue which holds central importance for every nation of the world.

Illness is an inevitable phenomenon in all human societies. Every society perceives this phenomenon and arranges the measures to cope with the circumstances created by it, in its own context. Therefore, beliefs about the phenomena of illness and practical measures taken by the society to cope with these phenomena, differ from society to society. These beliefs and practical measures are transformed from one generation to another and thus they continue for a long period of time.

\section{Locale of Study}

The present research was conducted in Village Zandra, District Ziarat, in Baluchistan, Pakistan. Zandra Village is situated $108 \mathrm{~km}$ southeast of Quetta just $12 \mathrm{~km}$ short of Ziarat town. The village is $8000 \mathrm{ft}$ above sea level and is surrounded by gray hills, apple orchards and Juniper forest, which is considered to be the $2^{\text {nd }}$ largest in the world. Thus, the area is greener than other areas of the province. Area wise Baluchistanis the largest province of Pakistan. It shares its northern border with Afghanistan with major cities of Chagai, Quetta and Zhob. The western border is shared with Iran via districts Makran and Kharan. The eastern end is bounded by the Sind province, whereas the Arabian Sea lies to its south.

\section{Research Methodology}

The methodology of the current research was based upon qualitative anthropological research methods. Methodology means philosophy of the research process which includes the assumptions and values that serve as a rationale for the research and the standards or criteria the research use of interpreting data and reaching conclusions. Whereas, by "method" we simply mean the research technique or tool used to gather data. The methods used for this research include socioeconomic survey, participant observation, key informant interviews, interviews, case studies and focus group discussions. For socioeconomic survey 100 households were selected through simple random sample. We choose two key informants in the village on our personal judgment basis, which knew most of the people in the village and their socio-economic conditions. The stratified random sampling technique was used. Target population was divided into economic classes and 50 couples were selected randomly from each class. Participant observation was used in order to get first hand and accurate information about the respondents. We participated in the daily activities of the village. In-depth interviews were conducted with the elder members of society to get detailed information. Case studies were conducted to get a detailed presentation of data related to different events. This research was a longitudinal study. First of all a 4-month visit was conducted in 1987, then a couple of month long visits in 1990s and finally in 2010. 


\section{Theoretical Framework}

While discussing the relationship between the developed and underdeveloped countries on health related issues most of the writers have used the term political economy of health. This term refers to the analysis of health policy and the development of health service in a broader macro-economic and political context. Lynn M. Morgan (1987) defines it as, "a macro analytic, critical, and historical perspective for analyzing disease distribution and health services under a variety of economic systems, with particular emphasis on the effects of stratified social, political, and economic relations within the world economic system."

The world systems theory or the development-of-underdevelopment school would be used to analyze the "under-development of health" in the peripheral region. It will focus on the unequal relationship between core and periphery on health care systems. Theoretical concept has been borrowed from works of Immanuel Wallerstein, A. G. Frank, and Walter Rodney, who logically believe that the development of capitalism in core countries requires a continuous and conscious underdevelopment of peripheral countries for regular supply of raw materials and cheap labour.

Some of the scholars were very enthusiastic and started analyzing social and health consequences of capitalist expansion at global level. World system theory became popular among the medical anthropologists like Onoge (1975), Morsy (1979), Baer (1983, 1986) and Singer (1986), who were trying to develop a relationship between political economy and medical anthropology. Some other medical anthropologists, including Wasserstrom (1979), Ferguson (1980), Nash and Kirsch (1986) while discussing about exploitative corporations and industries, have pointed out some harmful effects of development of capitalism on health care systems in peripheral regions. Their approach also supports the world system theory. Davison (1983) and Heggenhougen (1984) in their discussion about the relationship between socio-political configurations and health policies and DeWalt (1983) and Whiteford (1985) while talking about harmful nutritional impact of rapidly growing capitalist ventures have also highlighted the same issues.

Interest in the political economy of health revived in 1970s, when the dependency theory was put forward by Doyal and Pennell (1976), Elling (1976, 1977, 1978), Frankenberg and Leeson (1973), Kelman (1971, 1975), Lichtman (1971), Rossdale (1965) and Waitzkin (1978). Works of A. G. Frank (1969, 1972), W. Rodney (1974) and Wallerstein's world systems theory (1974) were an advanced version of the same theoretical concept, where underdevelopment means the transfer of wealth by exploiting periphery and semi-periphery by core countries which encourages rapid scientific development so that Western medicine and other scientific institutions could surpass underdeveloped countries of the world (Gish, 1979).

Some political economists of health (Turshen (1977) and Doyal (1979)) argue that the prevailing situation of poor health and health care systems in peripheral countries is due to the development of underdevelopment by creating technological and economic dependency on the international capitalist system. While explaining health, they borrowed the basic idea from Walter Rodney (1974)_who was influenced by Frank and Wallerstein. They borrowed these concepts because medical imperialism follows the same path as capitalist expansion. Main features of medical imperialism as pointed out by Doyal and Pennell (1976), J. Paul (1978), Waitzkin (1978), Elling (1981a) and Franco-Agudelo (1983) are as under:

1. It extracts human resource from the peripheral countries in the form of trained health workers who migrate to the core countries as part of the brain drain.

2. It helps to find out and maintain cheap labor for the capitalist industries.

3. It creates new markets for medicines, pesticides, medical equipment, and technical assistance.

4. It strengthens the class relations of core countries through the medical division of labor.

5. It provides cover for counter insurgency and other military efforts.

Berliner (1982) and Kelman (1975) say that capitalism and biomedicine support each other in their ideological constructs and share the same goals to create ambiguity for socioeconomic reasons of health and economic underdevelopment. World system theorists and political economists of health (Brown, 1979; Waitzkin \& Waterman, 1974; Elling, 1981a) propose the same solution to the problems related to dependency and under development, and that is to put an end to capitalism.

Elling (1981a) has pointed out an important issue in relationship of capitalism with health care systems. The goal of profit maximizing does not always match the goal of maintaining health. The desire for maximum profit leads the employers to pay the minimal remunerations and benefits to the workers due to which they cannot maintain their health. They cannot even purchase commodities and services like food, housing, and education. 
Often profit maximization does not allow the employer to provide a technically safe working environment and the industrial waste causes environmental pollution. A worker lining and working in such conditions cannot be a productive worker and the industrialist cannot risk low productivity.

In the light of the above discussion, we can say that most of the political economists of health have borrowed the theoretical concepts from world system theory. They analyze disease and medical care from the perspective of core periphery relationships. According to Elling (1981b), "There are whole sets of national and international health problems which might be better understood as interrelated problems of exploitation between core capitalist (industrialized) nations and peripheral (underdeveloped) nations”.

Most of the world system theorists have analyzed its implementation at the macro level. The exploitative relation between core and periphery has been studied at the state level. In this research, this model will be put to test at the micro level to confirm, revise or drastically change the reasoning built into this. Its impact would be observed on health care systems. The researcher would try to examine how this development of underdevelopment influences the masses at grass root level. Husain (1976) sees the impact of development at micro level. He talks about the impacts of the introduction of new technology on the human lives. He says, "The number of persons who are affected indirectly by the introduction of a new technology is much larger than the number of those who are displaced directly by it; the scale of the new technology is really large. Apart from persons who may directly be displaced by the establishment of a new factory, many in the rural community would probably be benefited or injured by the change in the matter of their income, health, amenities, etc."

Arnove (1980) has emphasized the need of further research at micro level. He says, "At the micro level, there is a need for further research along the lines of the Di Bona and Keith studies. Such studies would examine the consequences of educational reforms emanating from the international technical assistance networks on classroom interactions, on what is learned in school, on the educational careers and subsequent life chances of those groups who are the presumed beneficiaries of these innovations. At the same time, many of these reforms are resisted by students and teachers alike as impositions of foreign values, languages, institutional forms, and practice. More detailed descriptions, which place resistance to cultural impositions within their historical context and within a framework of power transactions, represent critically important contributions. Finally, there is a need for studies which examine the changes in the social relations of learning, educational aims and norms, the language and content of instruction as a society breaks with or is cut off from the international donor system and related economic and political systems."

During the last couple of years the researcher is trying to examine how this development of underdevelopment influences the masses at grass root level, especially in the field of economy, education and health (2012a, 2012b, 2012c, 2012d, 2012e, 2012f, 2012g, 2013a, 2013b, 2013c). Husain (1976) sees the impact of development at micro level. In the field of education Di Bona (1977) and Keith (1978) have studied the implementation of world system analysis at the micro level. Arnove (1980) has emphasized the need of further research at micro level.

\section{Results and Discussion}

People of Zandra perceive this phenomenon of the illness and practical measures in the context of their own culture. On the basis of their perception, they have developed certain measures to face the conditions created by the phenomena of illness. But after the provision of basic health facilities in certain parts of Balochistan by government and non-government health organizations, this situation has changed. In collaboration with these organizations people have adopted certain new measures to cope with the illness. This change (adoption of new measures) has also affected natives' perceptions about health and illness.

In the village health facilities have improved during last three decades. A Basic Health Unit (BHU) was setup in the year 1979 in the vicinity of Zandra village. This health unit had a medical officer, a lady health visitor, a technical assistant, one trained midwife and a peon. However, the staff of this health center has now increased up to 14 persons; three lady health visitors, two technical assistants, five trained midwives and two peons. The facility is open from 8 am to 2 pm during which time the doctor is always present at the premises. If need be emergency patients can visit the doctor at his residence round the clock. Provision of a resident doctor is a major boost to the health standards as opposed to the once a week visiting doctor back in the 1980's.

Medical supplies are provided free of cost to the patients at this health center. Over the last three decades the annual quota of medicines for this BHU has also been increased from Rs.48000 to Rs.400000. Two medical 
stores are operating in the village since 1998 from where the people can buy medicines. Consultation along with the medicines is also available at two recently opened private clinics which are located about 10 - $12 \mathrm{~km}$ from the village in Ziarat where the doctor's consultancy fee is also not very high. Doctor charges an average of Rs.200 per patient per visit which is easily affordable by the middle and upper class. Even the lower class can also afford it as the overall financial condition of the village has improved because of apple economy.

Stomach diseases due to unhygienic food and amoebic dysentery are very common diseases. Bronchitis due to dust is also a major problem in this area. At an average number of registered medical cases in BHU has increased from 400 to 1500 per month in the last three decades.

The development in the transport sector has played a major role in the improvement of the health standards of this area. With the availability of roads and public transport, access to bigger hospitals in Quetta has now become a possibility. Public transport includes busses and vans, which operate between Quetta and Ziarat. In 1980s, only one bus and two vans were operating but now these vehicles pass through the village after every hour right from the morning till evening. Travelling from the village has become easier. Other than this, people have their own cars and motorcycles.

As a result, there is a change in the natives' behaviour and in their health related beliefs. Opening of BHU and awareness brought about by electronic and print media has caused a shift in interest of the people from hakeems (herbalist) and the faith healers to allopathic treatment.The majority of the younger generation has adopted modem medicine as an alternative to the traditional medicine due to a regular supply of drugs by the Health Department and the influence of pharmaceutical companies.

Natives' practices for restoring and maintaining health in Zandra are determined by their beliefs about illness and health. The term practices, refers to all those activities adopted or developed by the natives to prevent themselves from illness and the activities adopted for the restoration of their health during illness. The term belief refers to all those beliefs prevailing in the village regarding the nature and causes of health and illness and also the beliefs about the modes of restoring health or prevention against illness.

In fact the village is in transition from traditional to modern way of life due to economic uplift, education in the area and local's contact with the outside world. During this transition, change has also occurred in the beliefs regarding the phenomena of health and illness and also in the mode of treatment used by the native people, which resulted in the adoption of an allopathic mode of treatment. The majority of the people aging above 60 years do not like the modern medicines because of their side effects. They think that the disease continues to persist and returns back in a different form at a different time. Moreover, these medicines produce dietary deficiencies by destroying the body's natural nutrients.

The natives believe in supernatural beings among the various causes of illness. It is also believed that there are a few faith healers who can communicate with these supernatural beings and can treat the patients. Among the supernatural beings, they include jin (giant), churel (female frightful supernatural being), bhoot (ghost), spirits, magic, evil eye and saya (shadow).

They have different measures against different illness causes, including (natural, biological, supernatural, psychological and food intake). The natives believe that illnesses caused by natural causes can be averted by keeping hygiene and taking pure food. Over work should be avoided and a doctor should be consulted even for minor illnesses. For supernatural causes of illness, natives consult the faith healers.

The majority of the people of Zandra define the phenomena of illness in terms of a condition in which body suffers from pain and in which an individual feels weak, lazy and the temperature in his body, becoming unable to perform his daily tasks. Even sometimes he cannot walk and talk. A 44-year-old male respondent defined illness as, "It is a sort of condition in which the body aches, suffers from temperature, leaving the person lazy and unable to do his daily routine work. Cholera is an example of an illness.” Most of the respondents defined illness as "pain in any part of the body". Thus, in this society, a person having pain in any part of the body is regarded as ill. Natives also give examples of illness by giving names of various illnesses such as headache, stomach ache, cholera, diarrhea, etc. Mental disorder is also regarded as an illness. During a group discussion, a 50 years old respondent said, "There is a person in his neighborhood who is mentally ill. He does not sleep the whole night and constantly cries for hours. This started taking place after the death of his twenty five years old son in a road accident."

People of Zandra also regard pregnancy as an illness, believing that a woman in pregnancy has to suffer from pain in the body and cannot perform her daily tasks in a proper way. Thus pain, weakness, laziness and temperature are the main symptoms of illness. Blood deficiency is also considered as the sign of illness and the amount 
of blood in the body is judged from the face colour. A respondent said that he had become pale due to blood deficiency in his body.

An absence of worry is also regarded as health. A 70-year-old male respondent, defined health as, "No pain and no worry is health". Sufficient amount of blood and flesh in the body is also regarded as health. Mostly people declare those people healthy who are fat and have a reddish face complexion (which is a sign of sufficient amount of blood in the body). Thus the natives of Zandra perceive good health in terms of absence of worry, pain-free body, ability of digestion and sufficient amount of blood and flesh in the body.

The causes of illness can be placed into six categories. The first category includes natural causes. In this category, they include germs, dirty environment, allopathic medicine, too much work and contact with the outsiders. The second category of causes can be termed as biological causes which include inherited illnesses, deficiency of blood and energy, and malfunctioning of the body organs. Illnesses caused by modern food habits are placed in the third category. Psychological causes are placed as category four. Supernatural and religious causes are treated as category five and six respectively. It is believed that one illness may have two causes from the same or two different categories.

Natives' beliefs are influenced by their religious beliefs, social interaction, educational level and access to mass media. The influence of education is evident on their beliefs regarding disease etiology. Young and educated people mention un-cleanliness and malfunctioning of the body organs as the cause illness. They also refuse to accept the supernatural forces causing illness. Uneducated people are getting aware through the educated people, doctors in the village and radio.

\section{Theoretical Discourse}

The above issues could be further discussed in the light of conceptual and theoretical concepts.

- Allopathic health facilities have been improved in the village with the help of NGOs and Government. Nothing has been done to improve the traditional healthcare systems, neither by the NGOs nor by the Government as both of them work on the agenda provided by the core countries to facilitate their pharmaceutical industry. NGOs work under their financial assistance and Governments under contracts signed against the receipt of grant in aid from those countries. It creates new markets for medicines, medical equipments, and technical assistance.

- Improvements in economic conditions, infrastructure, literacy level and mass media have also supported allopathic health care systems. With improved economic conditions the allopathic treatment has become affordable for the natives. It has also become a sign of status and prestige for them as they can get expansive treatment from private clinics. Infrastructure including roads and better transport facilities also support the pharmaceutical industry as the people can reach the hospitals and clinics even the cities. Education and the mass media have created awareness among the people to change their believe systems which resulted in the growth of pharmaceutical business and on the other hand a setback for faith healers and hakeems (herbalist) who have been searching for alternatives for their survival. The younger generation hardly believes in faith healers and traditional medical practitioners. The elder generation was conscious about the side-effects of allopathic medicines, even then a shift in their health believes was observed. Side-effects of allopathic medicines are providing permanent clientage to the pharmaceutical industry as you recover from one and gets into another.

- Pregnancies were never treated as an illness in the village. With the help of elderly women and the traditional birth attendants (TBA) deliveries were conducted at home. Doctors were not involved in it as it was considered as a physiological process. Now, as a result of awareness created by the core countries through education and the media the pregnancy has become an illness. There is a complete involvement of doctors, allopathic medicines and instruments. The patients are visiting the hospitals and clinics regularly, going through ultrasounds about 6 times during pregnancy. It all generates economic transactions supporting the capitalist's pharmaceutical industry. Natives have been spending huge amounts as compared to the past when they had to pay small amounts to the TBAs. This shift was put to an end to the traditional occupation.

- A change in the perception of illness was observed in the village. Natives defined the illness as inability to work. This perception has been developed in the minds by education and the media which clearly reflects the creation of the working class. So education and the media are motivating the people to use allopathic treatment on one hand and changing the perceptions on the other. People want to keep themselves fit for work 
and allopathic treatment helps them in this regard. Allopathic mode of treatment being created by the industry is paying back to it by controlling the labour and keeping the workforce physically and mentally fit for work.

The above discourse support the world system theory where the theorists have pointed out the intervention of core regions in health care systems of the peripheral countries to create markets for their pharmaceutical products and medical assistance. They also maintain a pool of cheap labor in peripheral countries for capitalist industries. This is all managed through financial assistance to the NGOs and grant in aid to the Governments, media campaigns, and educational institutions.

\section{Conclusion}

Man is change oriented by nature. He has always been striving for the richness of human life. Traces of this advancement could be found right from human prehistory which begins in the Paleolithic Era, what we call it "Early Stone Age". Later, it moved to Mesolithic Era, the Middle Stone Age and then to the Neolithic Era (New Stone Age) when the Agricultural Revolution started between 8000 and 5000 BC and the man started planned practice of cultivating the land or raising livestock. Agriculture begins to spread all over the world and human communities started expanding and living as farmers in permanent settlements. When productivity increased need for storage and transportation of food was felt. This resulted in the development of cities and division of labor. This process continued and the man started using machines for mass production in 18th century what we call the Industrial Revolution.

This Industrial Revolution brought some significant change in man's life. The concept of development changed from enhancement of the richness of human life to the richness of the economy in which a man lives. The economy actually was a part of the total development. Considerable progress has been made in human life in the past. Most the people are living healthier and a longer life. They are better educated and have a greater access to consumable products and services.

Since the Industrial Revolution development was treated as an economic phenomenon only with industrialization as its prerequisite. During the last couple of decades the pace of the development has really been increased. Even the economically poor peripheral countries are giving great importance to people's income resources, health and education. The data reveal that this pace of progress has also affected the village which has gone through some major structural changes during recent past. The natives are economically well off, which they consider as development. This development has increased their choices. They have a better access to education and health facilities. Their perception about biomedical healthcare has changed which reduced the clientele of the ethnic healthcare systems and increased the people's expenditures on health care.

According to world system theory core countries have an interest in the growth of the peripheral countries, because such a growth increases demand for the goods produced by the capitalist industry. This, in turn, will promote growth in the core countries. The reverse is also postulated to apply, that is the developing countries can sell more of their products in the industrial countries when the economies in these countries grow. The main point here is that it is not only the peripheral countries that depend upon the core countries, the core countries are in many areas dependent upon the periphery. So interdependence exists, for periphery, it is for finished products and for core it is for raw materials and human resource. This interdependence supports the core countries as the consumer products used in peripheral countries become a source of profit and inexpensive raw material and cheap labour provide them savings. So they are becoming richer and richer at the cost of the peripheral economies.

The world's capitalist economies determine the route for development of the large part of the world's population in their own favour. Industrialization is a precondition for aggregate growth and economic development of backward societies. Distorted production structure in the peripheral countries and their dependence is a result of the dominance of the core countries. The economically backward countries have to pledge considerable resources to set in motion an industrial development process. Technological development brings positive changes all over the world. Some impulsive changes are brought in peripheral or semi-peripheral countries, but the core countries get the most advantage.

In the end the researcher is in full agreement with the views of world system theorists (Doyal, Waitzkin, Elling and Franco-Agudelo) who have been working in the field of biomedical hegemony and political economy of health, following the concept of Wallerstein, Samir Amin, A. G. Frank, Meyer, Arnove and Ramirez). In the light of empirical data world system theory is found valid and accepted. 


\section{References}

Arnove, R. F. (1980). Comparative Education and World-Systems. Comparative Education Review, $24,48-62$. http://dx.doi.org/10.1086/446090

Baer, H. A. (1982). On the Political Economy of Health. Medical Anthropology Newsletter, 14, 13-17. http://dx.doi.org/10.1525/maq.1982.14.1.02a00010

Baer, H. A. (1986). Sociological Contributions to the Political Economy of Health: Lessons for Medical Anthropologists. Medical Anthropology Quarterly, 17, 129-131. http://dx.doi.org/10.1111/j.1937-6219.1986.tb01056.x

Berliner, H. S. (1982). Medical Modes of Production. In A. Treacher, \& P. Wright (Eds.), The Problem of Medical Knowledge. (pp. 162-173). Edinburgh: Edinburgh University Press.

Brown, E. R. (1979). Rockefeller Medicine Men. Berkeley: University of California Press.

Davison, L. H. (1983). Malnutrition in Haiti: A World Systems Perspective. Paper Presented at the American Anthropological Association Annual Meeting, Chicago.

DeWalt, B. (1983). Building a Policy-Relevant Anthropology of Agrarian Systems in Central America and Mexico. Paper Presented at the American Anthropological Association Annual Meeting, Chicago.

Di Bona, J. E. (1977). The Development of Educational Underdevelopment in India. Asian Profile, 6, 615.

Doyal, L. (1979). The Political Economy of Health. Boston, MA: South End Press.

Doyal, L., \& Pennell, I. (1976). Pox Britannica: Health, Medicine and Underdevelopment. Race and Class, 18, 155-172. http://dx.doi.org/10.1177/030639687601800203

Elling, R. H. (1976). Political Influences on the Methods of Cross-National Socio-Medical Research. In M. Pflanz, \& E. Schach, (Eds.), Cross National Socio-Medical Research Concepts, Methods, Practice (pp. 144-155). Stuttgart: Georg Thieme Publishers.

Elling, R. H. (1977). Industrialization and Occupational Health in Underdeveloped Countries. International Journal of Health Services, 7, 209-235. http://dx.doi.org/10.2190/MQDB-PRC3-9P6W-M76D

Elling, R. H. (1978). Medical Systems as Changing Social Systems. Social Science \& Medicine, 12, 107-115.

Elling, R. H. (1981a). The Capitalist World System and International Health. International Journal of Health Services, 11, 21-51. http://dx.doi.org/10.2190/JWM6-D2JC-RLFW-MWDC

Elling, R. H. (1981b). Introduction: Relations between Traditional and Modern Medical Systems. Social Science \& Medicine 15A, 87-88.

Ferguson, A. (1980). The Role of Pharmaceuticals in the Process of Medicalization of Latin America. Paper Presented at the American Anthropological Association Annual Meeting, Washington DC.

Franco-Agudelo, A. S. (1983). The Rockefeller Foundation's Antimalarial Program in Latin America: Donating or Dominating? International Journal of Health Services, 13, 411-427.

Frank, A. G. (1969). Capitalism and Underdevelopment in Latin America. New York: Monthly Review Press.

Frank, A. G. (1972). The Development of Underdevelopment. In J. D. Cockcraft, A. G. Frank, \& D. L. Johnson (Eds.), Dependence and Underdevelopment: Latin America's Political Economy (pp. 3-17). Garden City, NY: Anchor.

Frankenberg, R., \& Leeson, J. (1973). The Sociology of Health Dilemmas in the Post-Colonial World. In E. deKadt, \& G. Williams (Eds.), Sociology and Development (pp. 255-278). London: Tavistock.

Gish, O. (1979). The Political Economy of Health Care and Health by the People: An Historical Exploration. Social Science \& Medicine, 13C, 203-211.

Heggenhougen, H. K. (1984). Will Primary Health Care Efforts Be Allowed to Succeed? Social Science \& Medicine, 19, 217-224. http://dx.doi.org/10.1016/0277-9536(84)90213-2

Husain, M. (1976). Education and Culture. Karachi: National Book Foundation.

Keith, S. (1978). An Historical Overview of the State and Educational Policy in Jamaica. Latin American Perspectives, 5 , 37-52. http://dx.doi.org/10.1177/0094582X7800500204

Kelman, S. (1971). Towards the Political Economy of Medical Care. Inquiry, 8, 30-38.

Kelman, S. (1975). The Social Nature of the Definition Problem in Health. International Journal of Health Services, 5, 625642. http://dx.doi.org/10.2190/X5H6-TC5W-D36T-K7KY

Lichtman, R. (1971). The Political Economy of Medical Care. In H. P. Dreitzel (Ed.), The Social Organization of Health (pp. 265-290). New York: Macmillan.

Mohyuddin, A., \& Chaudhry, H. R. (2012). Impact of Technology on Traditional Irrigation System in Balochistan: World System Analysis in Anthropological Perspective. Asian Journal of Social Sciences and Humanities, 1, 127-138. 
Mohyuddin, A., Chaudhry, H. R., \& Ambreen, M. (2012). Contribution of Women in Economic Activities in Rural Balochistan: World System Analysis at Micro Level in Anthropological Perspective. Academic Research International, 3, 548556.

Mohyuddin, A., Chaudhry, H. R., \& Ambreen, M. (2012). Development in Education Sector in Zandra, Balochistan (Micro Analysis of World System Theory in Anthropological Perspective). Journal of Humanities and Social Science, 4, 40-44. http://dx.doi.org/10.9790/0837-0444044

Mohyuddin, A., Chaudhry, H. R., \& Ambreen, M. (2012). Economic Empowerment of Women in the Rural Areas of Balochistan. Pakistan Journal of Women's Studies: Alam-e-Niswan, 19, 239-257.

Mohyuddin, A., Chaudhry, H. R., \& Ambreen, M. (2012). Economic Structure of a Village in Balochistan: World System Analysis at Micro Level in Anthropological Perspective. International Journal of Economics, Commerce and Research (IJECR), 2, 79-98.

Mohyuddin, A., Chaudhry, H. R., \& Ambreen, M. (2012). Kinship System and Social Organization of a Village in Balochistan: World System Analysis at Micro Level in Anthropological Perspective. Academic Research International, 3, 322-335.

Mohyuddin, A., Chaudhry, H. R., \& Ambreen, M. (2012). Perception and Process of Development in Zandra, a Village in Balochistan: World System Analysis at Micro Level in Anthropological Perspective. Asian Journal of Management Sciences \& Education, 1, 66-79.

Mohyuddin, A., Chaudhry, H. R., \& Ambreen, M. (2013). Apple Economy of Village Zandra in light of World System Theory: Micro Level Analysis in Anthropological Perspective. Open Journal of Applied Sciences, 3, 39-43. http://dx.doi.org/10.4236/ojapps.2013.31006

Mohyuddin, A., Chaudhry, W., \& Ambreen, M. (2013). Changing Diagnostic Techniques and Modes of Treatment: Creating Biomedical Hegemony. La Pensée, 75, 47-60.

Mohyuddin, A., Khan, S., Chaudhry, H. R., \& Ambreen, M. (2013). Transition from Spiritual Healing to Modern Medicine: A World System Analysis at Micro Level. La Pensée, 75, 2-19.

Morgan, L. M. (1987). Dependency Theory in the Political Economy of Health: An Anthropological Critique. Medical Anthropology Quarterly, New Series, 1, 131-154.

Morsy, S. (1979). The Missing Link in Medical Anthropology: The Political Economy of Health. Reviews in Anthropology, 6 , 349-363. http://dx.doi.org/10.1080/00988157.1979.9977458

Nash, J., \& Kirsch, M. (1986). Polychlorinated Biphenyls in the Electrical Machinery Industry: An Ethnological Study of Community Action and Corporate Responsibility. Social Science \& Medicine, 23, 131-138. http://dx.doi.org/10.1016/0277-9536(86)90361-8

Onoge, O. F. (1975). Capitalism and Public Health: A Neglected Theme in the Medical Anthropology of Africa. In S. R. Ingman, \& A. E. Thomas (Eds.), Topias and Utopias in Health (pp. 219-232). The Hague: Mouton. http://dx.doi.org/10.1515/9783110888539.219

Paul, J. A. (1978). Medicine and Imperialism. In J. Ehrenreich (Ed.), The Cultural Crisis of Modern Medicine (pp. 271-286). New York: Monthly Review Press.

Rodney, W. (1974). How Europe Underdeveloped Africa. Washington DC: Howard University Press.

Rossdale, M. (1965). Health in a Sick Society. New Left Review, 34, 82-90.

Singer, M. (1986). Towards a Political-Economy of Alcoholism: The Missing Link in the Anthropology of Drinking. Social Science \& Medicine, 23, 113-130. http://dx.doi.org/10.1016/0277-9536(86)90360-6

Turshen, M. (1977). The Impact of Colonialism on Health and Health Services in Tanzania. International Journal of Health Services, 7, 7-35. http://dx.doi.org/10.2190/L9G4-KJVK-AW7A-Q9JD

Waitzkin, H. (1978). A Marxist View of Medical Care. Annals of Internal Medicine, 89, 264-278. http://dx.doi.org/10.7326/0003-4819-89-2-264

Waitzkin, H., \& Waterman, B. (1974). The Exploitation of Illness in Capitalist Society. Indianapolis, IN: Bobbs-Merrill.

Wallerstein, I. (1974). The Modern World System, Vol. I: Capitalist Agriculture and the Origins of the European World Economy in the Sixteenth Century. New York: Academic Press.

Wasserstrom, R. (1979). Nestle in Mexico: Hazardous to Your Health. In S. Guttmacher (Ed.), Imperialism, Dependency, and Health: HMO Packet 6 (pp. 1-4). New York: Health Marxist Organization, East Coast Discussion Group.

Whiteford, M. B. (1985). The Social Epidemiology of Nutritional Status among Costa Rican Children: A Case Study. Human Organization, 44, 241-250. 